\title{
Adherence to antihypertensive therapy among heart transplant recipients
}

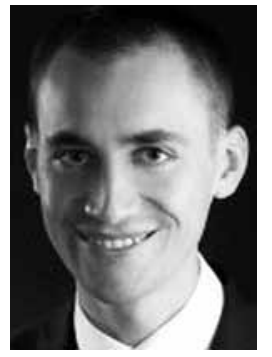

Department of Cardiovascular Surgery and Transplantology, Jagiellonian University, Medical College, John Paul II Hospital, Krakow, Poland

Kardiochirurgia i Torakochirurgia Polska 2014; 11 (3): 343-348

\begin{abstract}
Introduction: Adherence to therapeutic recommendations, concerning in particular drug administration, diet and healthy life style, is essential to obtain optimal medical treatment effects. Elevated blood pressure is an extremely important risk factor for cardiovascular diseases such as coronary artery disease, chronic heart failure and stroke, as well as chronic kidney disease.

Aim: The aim of the study was to assess the level of adherence among heart transplant recipients and to explain the reasons for non-adherence phenomenon.

Material and methods: The study was performed on 55 heart allograft recipients: 11 women (20\%) and 44 men (80\%), all hypertensive. Participation in the study was voluntary and the three-part questionnaire was anonymous to obtain reliable answers. The second part was designed using the Modified Morisky Scale (MMS) consisting of questions assessing motivation and knowledge among patients. The third included questions concerning lifestyle, reasons for non-adherence and methods to improve it.
\end{abstract}

Results: In self-assessment of the adherence to medical recommendations on a scale of 0 to 10 the analyzed population estimated their level of adherence to be on average $8.49 \pm$ 1.33 , which is a considerably high result. It was discovered that both the level of motivation (2.20) and knowledge (2.83) are high among heart transplant recipients. Still, the level of knowledge was significantly higher than the motivation $(p<0.005)$. Correlation analysis revealed that the self-assessed adherence level correlated positively with the level of motivation $(r=0.357 ; p<0.007)$.

Conclusions: Creation of an active attitude of the patient in the process of treatment is a crucial and at the same time often difficult task demanding cooperation of the patient, the patient's close family and the whole therapeutic team.

Key words: adherence, hypertension, heart transplantation.

\section{Introduction}

Adherence to therapeutic recommendations concerning above all drug administration, diet and healthy life style

\section{Streszczenie}

Wstęp: Adherence, czyli przestrzeganie zaleceń terapeutycznych, przede wszystkim w zakresie przyjmowania leków, odpowiedniej diety i stylu życia, jest niezbędne do osiągnięcia optymalnych efektów leczenia. Nadciśnienie tętnicze jest istotnym czynnikiem ryzyka chorób sercowo-naczyniowych, takich jak choroba niedokrwienna serca, niewydolność serca, udar, przewlekła niewydolność nerek.

Cel: Ocena stopnia przestrzegania zaleceń terapeutycznych wśród biorców przeszczepu serca i analiza przyczyn występowania zjawiska non-adherence.

Materiat i metody: Badanie przeprowadzono wśród 55 osób po przeszczepieniu serca; 11 kobiet (20\%) i 44 mężczyzn (80\%), chorujących na nadciśnienie tętnicze. Dobrowolne uczestnictwo w badaniu wiązało się z uzupełnieniem anonimowego, 3-częściowego kwestionariusza. Druga część została zaprojektowana na bazie zmodyfikowanej skali Moriskyego (MMS) oceniającej poziom motywacji i wiedzy wśród badanych. Trzecia część dotyczyła stylu życia, powodów nieprzestrzegania zaleceń i sposobów na poprawę stopnia adherence.

Wyniki: W samoocenie przestrzegania zaleceń terapeutycznych na skali od 0 do 10 badana populacja oszacowała swój poziom na średnio 8,49 $\pm 1,33$, co jest wysokim wynikiem. Wykazano, że zarówno poziom motywacji $(2,20)$, jak i wiedzy $(2,83)$ jest wysoki wśród biorców przeszczepu serca. Poziom wiedzy był jednak istotnie wyższy niż motywacja $(p<0,005)$. Analiza korelacji wykazała, że samodzielna ocena przestrzegania zaleceń korelowała z poziomem motywacji $(r=0,357 ; p<0,007)$.

Wnioski: Wytworzenie aktywnej postawy pacjentów w procesie terapeutycznym jest kluczowym i jednocześnie bardzo trudnym zadaniem wymagającym współpracy samego chorego, jego najbliższej rodziny i całego zespołu terapeutycznego. Słowa kluczowe: adherence, nadciśnienie tętnicze, przeszczep serca.

is essential to obtain optimal medical treatment effects in almost all contemporary diseases. Moreover, it is a challenge of great importance for the whole therapeutic group.

Address for correspondence: Grzegorz Jan Wasilewski MD, Department of Cardiovascular Surgery and Transplantology, Jagiellonian University, Medical College, John Paul II Hospital, Prądnicka 80, 31-202 Krakow, Poland, phone: +48 502 544 671, e-mail: grzegorz.wa@interia.pl 
In Poland there is still a lot to be done in this field. According to research by the Scientific Foundation of Polpharma, every fourth Polish patient does not obey the therapeutic recommendations [1]. The consequence of non-adherence are considerable for both the patient and the whole $\mathrm{Na}$ tional Health Care System. The effectiveness of treatment deteriorates; there is growing demand for medical consultations and the number of hospitalizations rises. It all causes the necessity of health care system expenses at more advanced disease stages and occurrence of complications. The research by Kardas et al. from the Medical University of tódź shows that the additional cost for the Polish Health Care System was estimated to be about PLN 6 billion per year [2]. Non-adherence is to blame for medical and psychological complications of basic diseases. It reduces the quality of the patient's life, increases the probability of drug resistance and reduces the patient's trust in the health care system [3].

Adherence means not only taking medications but also the acceptance of the whole therapeutic instructions and thus the extent to which the patient's behavior is in line with the doctor's therapeutic recommendations [4]. Previously the term compliance was used more often to define this specific bond between the patient and his doctor. Compliance means the degree of medical advice conformity with the patient's behavior (in the scope of pharmacotherapy, diet and life style changes) [5]. Recently it was suggested that this attitude treats the relationship between patient and doctor as paternalistic and the whole fault for medical recommendations noncompliance was placed on the patient only. Meanwhile the patient should play an active part in the process of forming medical recommendations and thus feel jointly responsible for adherence. Thereby the patient becomes a partner for a doctor, nurse and all other people involved in the therapeutic process. It is mostly important in chronic diseases whose natural history is long-lasting, are associated with considerable suffering and irreversible pathophysiological changes, and which often require consideration of rehabilitation and systematic medical examination.
The factors influencing adherence are presented in Table I $[6,7]$.

To sum up all the factors affecting non-adherence on the basis of results of research published in Evidence Based Medicine, we could distinguish a few main categories [8]: 1) side effects identification and the way of handling them (omitting dosage, giving up therapy),

2)attitudes and actions concerning taking medications (modifying dosage according to the daily activity - too much/ too little. Beliefs about the effectiveness of one's actions),

3) psychological, sensory, cognitive disorders influencing drug taking. (forgetting to take medications, inappropriate dosage),

4) lack of information concerning the directions for the medications use,

5) availability of health care system.

Cardiovascular diseases are the major causes of death in Poland. Among them hypertension seems to occur the most often. Appropriate treatment of cardiovascular diseases requires consistent adherence to the recommendations for medication, physical activity, diet obedience, healthy lifestyle and monitoring systemic blood pressure, weight and cholesterol levels. Only in this way it is possible to achieve and maintain good health of our population. In patients with hypertension, adherence to the treatment recommendations has a major impact on health outcomes and the costs of care. We enrolled in the study a specific group of patients who are usually well educated and with stronger motivation than the average person. Our cohort consisted of 55 heart transplant recipients. Patients enrolled in the study were all suffering from hypertension. We asked our individuals to honestly complete the anonymous questionnaire concerning adherence, focusing clearly on the therapy of hypertension excluding the immunosuppressive regimen.

\section{Material and methods}

The study was performed on 55 heart allograft recipients. There were 11 women (20\%) and 44 men (80\%). Par-

Tab. I. Factors influencing adherence

Emotional factors (internal)

On the part of the patient
Attitude to the disease and the necessity of therapy Psychopathological symptoms (depression, anxiety) Attitude of community/family Patient's attitude to the medications Trust in the health care system

\section{Rational factors (external)}

Lifestyle (career activity, diet, alcohol and drugs overuse)

Family; community support

Gender

Age (younger/the aged)

Knowledge of medical consequences of the disease Level of education

On the part of a doctor/other Quality of the relation between patient and doctor/ Access to the doctor

health professionals nurse/other
Attitude toward patient

Frequency and duration of medical consultations Access to medical examination/laboratory tests Cost of the therapy

Connected to the disease Attitude toward the necessity of hospitalization
Duration of the disease

Existence of perceptible symptoms of the disease

Therapeutic regimen

Side effects of the therapy

Negative conviction about the effects of medications

Outcome of treatment 
Tab. II. Modified Morisky scale

\begin{tabular}{|c|c|c|}
\hline Question & Motivation & Knowledge \\
\hline 1. Do you ever forget to take your medicine? & $\begin{array}{l}\text { Yes }(0): 22 \\
\text { No (1): } 33\end{array}$ & \\
\hline 2. Are you careless at times about taking your medicine? & $\begin{array}{l}\text { Yes (0): } 21 \\
\text { No (1): } 34\end{array}$ & \\
\hline 3. When you feel better do you sometimes stop taking your medicine? & & $\begin{array}{l}\text { Yes (0): } 2 \\
\text { No (1): } 53\end{array}$ \\
\hline 4. Sometimes if you feel worse when you take your medicine, do you stop taking it? & & $\begin{array}{l}\text { Yes }(0): 3 \\
\text { No (1): } 52\end{array}$ \\
\hline $\begin{array}{l}\text { 5. Do you know the long-term benefit of taking your medicine as told to you by your doctor } \\
\text { or pharmacist? }\end{array}$ & & $\begin{array}{l}\text { Yes (1): } 50 \\
\text { No (0): } 5\end{array}$ \\
\hline 6. Sometimes do you forget to refill your prescription medicine on time? & $\begin{array}{l}\text { Yes (0): } 1 \\
\text { No (1): } 54 \\
\end{array}$ & \\
\hline Total score & $\begin{aligned} & 2.20 \\
& 0-1=\text { Low motivation } \\
& 2-3=\text { High motivation }\end{aligned}$ & $\begin{array}{c}2.83 \\
0-1=\text { Low knowledge } \\
2-3=\text { High knowledge }\end{array}$ \\
\hline
\end{tabular}

Motivation vs. knowledge, $p<0.005$

ticipation in the study was voluntary and the questionnaire was completely anonymous to obtain reliable answers. Patients enrolled in the study were asked to complete the questionnaire consisting of three parts. The first one focused on the basic demographic data and social status. The second was designed using the Modified Morisky Scale consisting of 6 questions assessing motivation and the level of knowledge among patients (Table II) [11]. The questions were designed to be answered "yes" or "no". Motivation was assessed on the basis of answers to questions 1, 2 and 6 and knowledge to questions 3, 4 and 5. To interpret the outcomes the average score between 0 and 1 means low motivation/knowledge; between 2 and 3 means high motivation/knowledge. Additionally we asked individuals taking part in the study to assess the level of their adherence on their own on a graphic scale with a range from 0 to 10. The third part of the questionnaire included questions of our own authorship concerning lifestyle, reasons for non-adherence and methods to improve adherence from the patient's perspective.

Data were expressed as means \pm SD. The data given were analyzed using Statistica 10.0 and Microsoft Excel computer software. The examination of the distribution normality of variables was done using the Shapiro-Wilk $W$ test. The Mann-Whitney rank sum $U$ test or Student's $t$-test was used in statistical analysis to compare differences between groups with $p<0.05$ considered statistically significant, when appropriate.

\section{Results}

The average age of patients was $54.7 \pm 13.2$ years, range from 24 to 75 . Thirty-four individuals (62\%) live in a town whereas 21 (38\%) live in a village. Only 10 patients (18\%) were working professionally whereas 45 (78\%) were retired or were pensioners. Taking into consideration education of enrolled patients, 10 individuals (18\%) had primary education; 36 (66\%) had secondary and only $9(16 \%)$ had higher education. The majority of patients were married
( $n=40,73 \%)$ whereas only 2 patients (4\%) were divorced; 4 were widows/widowers (7\%) and 9 (16\%) were not married. The most common comorbidity indicated by the patients was hypertension ( $n=39,71 \%$ ), which was in agreement with our knowledge about health problems of the studied population and which confirmed that the awareness of the disease among patients is still not satisfactory. All the patients enrolled in the study were hypertensive according to 24-hour arterial blood pressure monitoring. The average percentage of irregular blood pressure measurements in 24-hour examination among the studied group was 32 $\pm 29 \%$ (median $19 \%$ ) of systolic and $22.27 \pm 24.6 \%$ (median $15 \%)$ of diastolic blood pressure. Twenty-six individuals (47\%) suffered from chronic kidney disease; 11 (20\%) had coronary artery disease and 9 (16\%) were diabetics. Twenty-eight heart transplant recipients (51\%) had more than one comorbidity.

In self-assessment of the adherence to medical recommendations on a scale of 0 to 10 the analyzed population estimated their level of adherence to be on average 8.49 \pm 1.33 , which is a considerably high result. Seventeen patients (31\%) assessed their level of adherence to be very high and only 3 individuals (5.5\%) claimed that their level of adherence is poor $(\leq 5)$.

In the process of assessing the adherence concerning pharmacotherapy of cardiovascular diseases according to the Modified Morisky Scale, it was affirmed that half of the population (53\%) sometimes forget to take the medicine at the scheduled time or even to take it at all. At the same time almost all patients $(n=54 ; 98 \%)$ do not forget to refill the prescription for their medications on time. Those parameters were designed in the study to investigate the level of motivation among patients. To assess the knowledge of the studied cohort about pharmacotherapy of hypertension, we asked whether patients tend to abort pharmacotherapy according to their mood or the results of blood pressure measurements. $95 \%$ of the respondents continue pharmacotherapy despite above-mentioned con- 
ditions. Moreover, 91\% answered that they are aware of the long-term benefits of taking the medications and that they were informed about that by their doctor or pharmacist (Table II). To sum up, it was discovered that both the level of motivation (2.20) and knowledge (2.83) are high among heart transplant recipients. Still, the level of knowledge was significantly higher than the motivation $(p<0.005)$. Correlation analysis revealed that self-assessed adherence level correlated positively with the level of motivation ( $r=$ 0.357; $p$ < 0.007). Moreover, we found a positive correlation between the mood of the patients and the level of sport activity $(r=0.78 ; p<0.005)$. There was no statistically significant difference between gender, the place of living or educational status and the level of self-assessed adherence to medical recommendations. The number of prescribed medicines also did not correlate with adherence.

The life-style assessment was based on three parameters: frequency of sport practice, smoking and alcohol intake. $89 \%$ of the respondents are active at least once a week ( $25 \%$ do some kind of sport activity on a daily basis). Only $11 \%$ of patients claim that they do not do any kind of sport activity. Unfortunately, there are still individuals who smoke at least a few times a week $(n=6 ; 11 \%)$. Seventy-eight percent of the patients admitted drinking alcohol at least once a week. Twenty-seven percent do almost every day. The other parameter tightly related to life-style and highly influencing potential hypertension is the weight of the patients and the awareness of existing overweight. The medium BMI (body mass index) among the group was $26.3 \pm 3.9$. Sixteen patients (29\%) incorrectly estimated their weight according to BMI interpretation, claiming that their weight is appropriate to the body height. Interestingly, there was no correlation between BMI and physical activity. Another factor of great importance influencing the adherence to medical recommendations and life-style changes is the frame of mind of the patient. To the question 'How do you assess your mood?', $80 \%(n=44)$ responded good or very good. Only 11 individuals (20\%) find their mood to be average. None of the patients responded that they feel negative.

The last part of the questionnaire was designed to examine the reasons why the patients do not obey the medical recommendations. The most common answer was the high cost of medicines and the fear of side effects and interactions of prescribed drugs (Fig. 1). Analogically, our respondents claim that the reduction of expenses on medicines and personal beliefs are main factors that could improve their adherence (Fig. 2).

\section{Discussion}

Creation of an active attitude of the patient in the process of treatment is a crucial and at the same time often difficult task, demanding cooperation of the patient, the patient's close family and the whole therapeutic team. A necessary condition for optimal treatment effects is not only prescribing medications according to the best medical knowledge but also their conscientious intake together with obeying many recommendations determining selfcontrol and self-treatment. Following all those rules in everyday practice requires time and dedication of engaged people. Many researchers have recently paid attention to the role of the patient as the partner of the doctor and other medical professionals. Positive attitude and engagement of the patient in the therapeutic process could be as important as administration of the most innovative drugs. Recently it is becoming more obvious that we should take advantage of applying those methods that are within our reach to improve the prognosis of patients with cardiovascular diseases. The reality in our clinics is that the adherence to medical recommendations is a serious problem for many patients. This phenomenon poses many threats, particularly in the treatment of chronic diseases such as

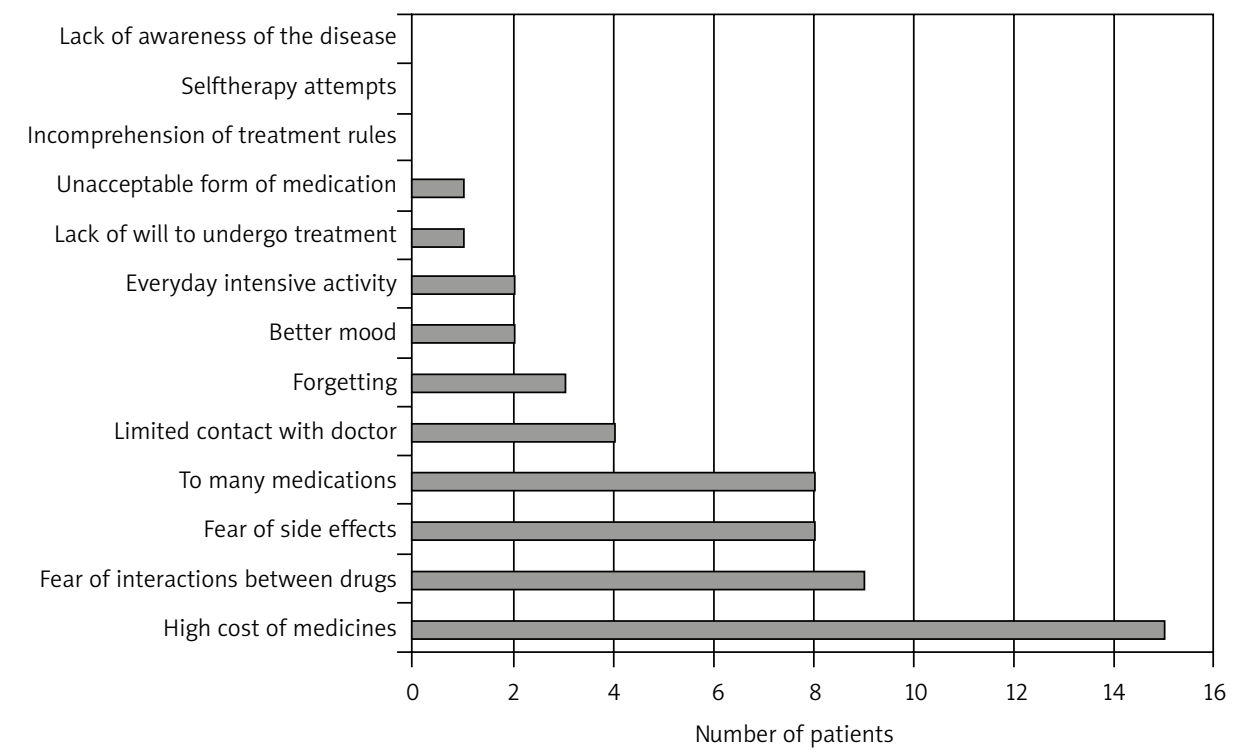

Fig. 1. The reasons for non-adherence 


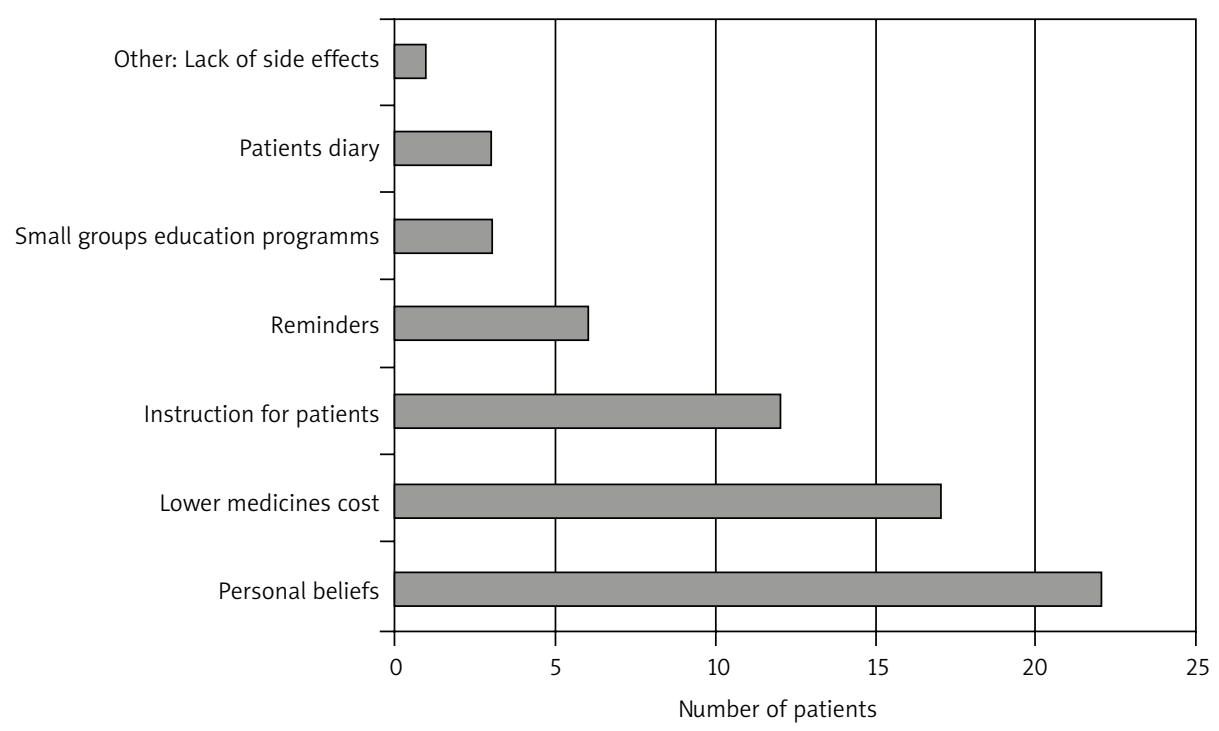

Fig. 2. The factors that could improve the adherence

hypertension and chronic heart failure [12]. To describe the dependencies arising from the doctor-patient relationship we use the terms compliance, adherence, persistence-cooperation, consistency and perseverance. Compliance and adherence are used to describe the level of obeying medical recommendations and thus conformity of the patient's medicine taking with the established therapeutic schedule $[13,14]$. Persistence means the period of time for which the patient takes prescribed medications according to the recommendations. Some authors define adherence to be the combination of compliance and persistence.

Patients after solid organ transplant, especially heart and kidneys, are very prone to suffer from hypertension. Elevated blood pressure is an extremely important risk factor for cardiovascular diseases such as coronary artery disease, chronic heart failure and stroke, as well as chronic kidney failure. Optimal blood pressure should be lower than $140 / 90 \mathrm{mmHg}$ in the general population, while among patients with chronic kidney disease (CKD) or diabetes it should be even lower than 130/80 $\mathrm{mmHg}$, according to the European Society of Hypertension/European Society of Cardiology and Joint National Committee 7 guidelines $[9,10]$. Despite the optimal medical therapy, blood pressure control in this group is far from satisfactory. This is connected to the immunosuppressive regimen side effects and coexisting comorbidities. For many years after heart transplantation patients are administered to hospital for routine follow-up tests. They are used to regular contact with medical professionals and they are aware of the necessity of obeying medical recommendations [15]. In the study we focused on the treatment of cardiovascular diseases excluding immunosuppressive therapy. Our research revealed that the level of knowledge among the studied group was very high. The level of motivation also reached the highest range, but was considerably lower than the knowledge. Taking into consideration the fact that more than half of the respondents happen to forget to take the medications on time or to take it at all, there is still a lot to be done in the area of motivation improvement [16]. What is more, we should still encourage our patients to change destructive habits such as smoking and alcohol intake, together with increasing the time spent on sport activities.

\section{Disclosure}

The authors report no conflict of interest.

\section{References}

1. Raport o przestrzeganiu zaleceń terapeutycznych przez polskich pacjentów: Polskiego pacjenta portret własny. Fundacja na Rzecz Wspierania Rozwoju Polskiej Farmacji i Medycyny, Warszawa 2010.

2. Kardas P. Nieprzestrzeganie zaleceń terapeutycznych na świecie i w Polsce. Polskiego Pacjenta portret własny. Fundacja na Rzecz Wspierania Rozwoju Polskiej Farmacji i Medycyny, Starogard Gdański 2010; 25-35.

3. Balkrishnana R. The importance of medication adherence in improving chronic disease related outcomes: what we know and what we need to further know. Medical Care 2005; 43: 517-520.

4. Sabaté E. WHO Adherence Meeting Report. World Health Organization, Geneva 2001.

5. Sackett DL. Compliance with therapeutic regimens. John's Hopkins University Press, Baltimore 1976.

6. Siegal BR, Greenstein SM. Postrenal transplant compliance from the perspective of African-Americans, Hispanic-Americans, Anglo-Americans. Adv Ren Replace Ther 1997; 4: 46-54.

7. Sherry DC, Simmons B, Wung SF, Zerwic JJ. Noncompliance in heart transplantation: A role for the Advanced Practice Nurse. Prog Cardiovasc Nurs 2003; 18: 141-146.

8. Gordon K, Smith F, Dhillon S. Effective chronic disease management: patients' perspective on medication-related problems. Patient Educ Couns 2007; 65: 407-415.

9. Morisky DE, Green LW, Levine M. Concurrent and predictive validity of a selfreported measure of medication adherence. Med Care 1986; 24: 67-73.

10. Tykarski A, Brzezinska U. Antihypertensive therapy and compliance. Arterial Hypertension 2005; 9: 217-227.

11. Gaciong Z, Kuna P. Adherence, compliance, persistence - współpraca, zgod ność i wytrwałość - podstawowy warunek sukcesu terapii. Med Dyp 2008; 3: 2-5.

12. Pudło H, Gabłońska A, Respondek M. Adherence to Medical Recommendations for Patients with Cardiovascular Disease. Piel Zdr Publ 2012; 2: 193-200.

13. Mancia G, De Backer G, Dominiczak A, Cifkova R, Fagard R, Germano G, Grassi G, Heagerty AM, Kjeldsen SE, Laurent S, Narkiewicz K, Ruilope L, 
Rynkiewicz A, Schmieder RE, Boudier HA, Zanchetti A, Vahanian A, Camm J, De Caterina R, Dean V, Dickstein K, Filippatos G, Funck-Brentano C, Hellemans I, Kristensen SD, McGregor K, Sechtem U, Silber S, Tendera M, Widimsky P, Zamorano JL, Erdine S, Kiowski W, Agabiti-Rosei E, Ambrosioni E, Lindholm LH, Viigimaa M, Adamopoulos S, Agabiti-Rosei E, Ambrosioni E, Bertomeu V, Clement D, Erdine S, Farsang C, Gaita D, Lip G, Mallion JM, Manolis AJ, Nilsson PM, O'Brien E, Ponikowski P, Redon J, Ruschitzka F, Tamargo J, van Zwieten P, Waeber B, Williams B; Management of Arterial Hypertension of the European Society of Hypertension; European Society of Cardiology. J Hypertens 2007; 25: 1105-1187.

14. Chobanian AV, Bakris GL, Black HR, Cushman WC, Green LA, Izzo JL Jr, Jones DW, Materson BJ, Oparil S, Wright JT Jr, Roccella EJ; National Heart,
Lung, and Blood Institute Joint National Committee on Prevention, Detec tion, Evaluation, and Treatment of High Blood Pressure; National High Blood Pressure Education Program Coordinating Committee. JAMA 2003; 289: 2560-2572.

15. Milaniak I, Makieła W, Przybyłowski P, Wierzbicki K, Sadowski J. Jak poprawić przestrzeganie zaleceń u pacjentów po przeszczepieniu serca? Przegląd piśmiennictwa i doświadczenia własne. Piel Chir Angiol 2011; 2: 99-106.

16. Szczęch R, Szyndler A, Kolasińska-Malkowska K, Narkiewicz K, Tykarski A. Możliwości poprawy skuteczności leczenia nadciśnienia tętniczego poprzez zwiększenie przestrzegania zaleceń przez pacjentów korzyści stosowania leków łączonych. Nadciśnienie Tętnicze 2007; 11: 525-535. 